\title{
Evidence for benthic body size miniaturization in the deep sea
}

\author{
Janne I. Kaariainen* and Brian J. Bett \\ DEEPSEAS Group, National Oceanography Centre, Southampton, SOl4 3ZH, UK. \\ *Corresponding author, e-mail: jik1@noc.soton.ac.uk
}

\begin{abstract}
The benthic body size miniaturization hypothesis states that deep-sea communities are dominated by organisms of smaller body size, although some field studies have produced contradictory results. Using appropriate sample sets, this study tests this hypothesis by contrasting the benthic communities of the Fladen Ground (North Sea, $150 \mathrm{~m}$ ) and the Faroe-Shetland Channel $(1600 \mathrm{~m})$. Samples were collected for large $(500 \mu \mathrm{m})$ and small macrofauna $(250-355 \mu \mathrm{m})$, meiofauna $(45 \mu \mathrm{m})$ as well as an intermediate sized 'mesofauna' $(180 \mu \mathrm{m})$ to ensure comprehensive coverage of the full meio- and macro-faunal body size-range. The body size structure of the benthos was compared using two methods. The more widely used average individual biomass method involves dividing the total sample biomass by sample abundance. Additionally, body size accumulation curves were constructed by assigning all specimens into a logarithmic size-class and then plotting the cumulative percentage of individuals present in each size-class. The results seem to support the hypothesis that the deep-sea environment is a small organism habitat. Although these findings only represent two locations, the overall body size accumulation curves clearly display a statistically significant shift towards smaller body sizes at the deeper site. The magnitude of the effect is appreciable with median metazoan body size reducing from $14.3 \mu \mathrm{g}$ wet weight in the Fladen Ground to $3.8 \mu \mathrm{g}$ wet weight in the Faroe-Shetland Channel. The average individual biomass measurements are shown to be of limited value and can lead to potentially misleading conclusions if the underlying sizestructure is not analysed in detail.
\end{abstract}

\section{INTRODUCTION}

Deep-water benthic organisms generally depend on food originating from the overlying surface waters. As both the quantity and the quality of food decrease with water depth and distance from the shore (Rowe \& Staresinic, 1979; Suess, 1980) benthic standing stock can also be expected to follow the same trend. Deep-sea organisms have been suggested to adapt to these decreased food levels in one of two ways. Some taxa [Gastropoda (Clarke, 1960); Isopoda (Wolff, 1962); Amphipoda (Thurston, 1979)] have been shown to increase in size (gigantism), potentially allowing them to forage further in search of limited food resources. On the other hand meio- and macro-faunal communities have shown trends towards body size miniaturization with increased water depth. Thiel (1975) formulated a hypothesis stating that 'associations governed by constantly limited food availability are composed of smaller individuals on average' and attributed this to the fact that food limitation does not allow the higher energy consumption of larger organisms on a local scale (Thiel, 1979).

Subsequent studies attempting to investigate body size miniaturization in the deep-sea have produced conflicting results with some studies providing support (Gage, 1977; Carey, 1981; Soetaert \& Heip, 1989; Soltwedel et al., 1996) and others contradicting it (Shirayama, 1983; Smith \& Hinga, 1983; Tietjen, 1989). The variable sampling and sorting methods used in these studies may in part explain some of these contradictory results. For example, Polloni et al. (1979) and Shirayama (1983) outlined the need to compare samples that were both spatially and temporally consistent, relevant and reliable. Most of the studies have also attempted to analyse benthic size-structure in terms of average individual biomass values, although potentially more can be revealed by investigating the underlying body size distribution patterns in detail.

One technique that allows the comparison of samples of differing size is to adapt an approach based on dominance curves (Lambshead et al., 1983; Clarke, 1990; Magurran, 2004). In the case of gauging potential differences in benthic size-structure between the two sites the construction of body size accumulation curves can serve this purpose. This is a graphical presentation where organisms are assigned into X2 geometric size-classes (each sizeclass is twice the body weight of the class below, as described by Warwick, 1984). The choice of a logarithmic scale is useful in visualizing the large range of body sizes and has been widely used in other studies. With this approach all specimens are assigned to a body size-class and the cumulative percentage of individuals present in each size-class is plotted. This can be particularly useful in assessing the relative contributions of different sizeclasses to the size distribution as a whole. With access to appropriate, high quality sample sets, this study aims to investigate body size miniaturization of benthic infaunal assemblages with increasing water depth and to compare the relative merits of using average individual biomass and cumulative body size distribution methods. 

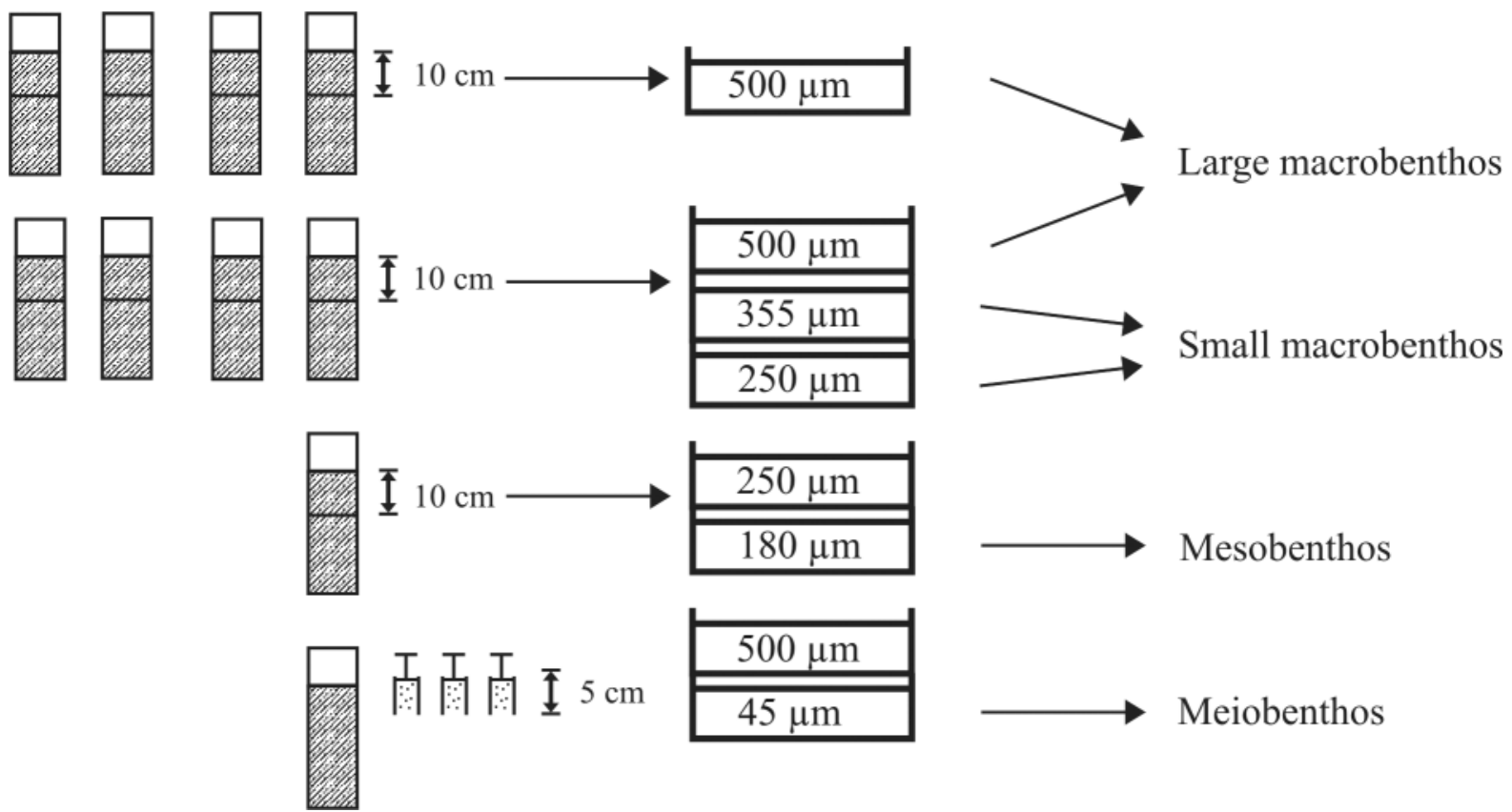

Meiobenthos

Figure 1. Schematic representation of the core sample processing procedure.

\section{MATERIALS AND METHODS}

\section{Description of the study sites}

Samples were collected from two locations. The Fladen Ground site is located in the northern North Sea $\left(58^{\circ} 15^{\prime} \mathrm{N}\right.$ $00^{\circ} 45^{\prime} \mathrm{E}$ ) and forms part of a flat muddy ground with a depth of about $150 \mathrm{~m}$. The area has extensive oil industry activity and may be subjected to considerable fishing pressure (Jennings et al., 1999). The annual range of bottom temperatures in the Fladen Ground varies between 6 and $8^{\circ} \mathrm{C}$ (McIntyre, 1961; Lee, 1980). The Faroe-Shetland Channel (FSC) site is located to the north-west of Shetland $\left(61^{\circ} 55^{\prime} \mathrm{N} 02^{\circ} 48^{\prime} \mathrm{W}\right)$. This is an essentially pristine, deep-water site $(1600 \mathrm{~m})$ characterized by bottom water temperatures typically less than $-0.5^{\circ} \mathrm{C}(-0.5$ to $-1.0^{\circ} \mathrm{C}$; Turrell et al., 1999). The sediment environment at both sites consists essentially of coarse silt with a relatively high percentage of fines $(>80 \%)$. Primary production estimates for the Fladen Ground site vary from 0.5 to $3.2 \mathrm{~g} \mathrm{C} \mathrm{m}^{-2} \mathrm{~d}^{-1}$ (Cadée, 1986) and for the FSC site from 1.2 to $1.8 \mathrm{~g} \mathrm{C} \mathrm{m}^{-2} \mathrm{~d}^{-1}$ (Riegman \& Kraay, 2001).

\section{Sample collection}

Sampling at both sites took place in September 2000 during RRS 'Charles Darwin' cruise 123. Replicate samples were collected for large $(500 \mu \mathrm{m})$ and small macrofauna $(250-355 \mu \mathrm{m})$, meiofauna $(45 \mu \mathrm{m})$ as well as an intermediate sized 'mesofauna' $(180 \mu \mathrm{m})$ from each location using a Bowers \& Connely 'Megacorer' (Gage \& Bett, 2005). This is a device that holds up to 12 individual core tubes $(10 \mathrm{~cm}$ diameter) and has a hydraulically damped action, which helps to reduce core compaction and any potential loss of the flocculent sediment surface layer and its associated fauna (Bett \& Gage, 2000). The inclusion of the intermediate sizes of small macro- and meso-fauna is an important part of the sampling design in size-structure studies. The analysis of size-structure from only conventional macro- and meio-faunal samples could lead to potential gaps in the resulting size-spectra at the intermediate body sizes as these organisms are not reliably retained at the mesh sizes used for macrobenthos (i.e. $500 \mu \mathrm{m}$ ). Similarly, the surface area covered by meiobenthic samples is generally not sufficient to reliably account for mesobenthic organisms.

The Megacorer was deployed repeatedly until five successful sample replicates were obtained at both sites. A successful sample consisted of at least nine acceptable cores, where the acceptance was based on sufficient sediment penetration $(>20 \mathrm{~cm})$ and level surface of the sediment sample with the sediment-water interface intact. Upon recovery of each replicate, acceptable cores were removed from the corer and transferred to the ship's laboratories for subsequent processing. The macrobenthos cores were extruded and sectioned to a $10 \mathrm{~cm}$ horizon with successive cores being pooled to produce a nominal sample size of $7-8$ cores $\left(550-628 \mathrm{~cm}^{2}\right)$. Up to four of the macrofauna cores were elutriated through 500, 355 and $250 \mu \mathrm{m}$ sieve meshes and the remaining cores through $500 \mu \mathrm{m}$ only, to produce separate large and small macrofauna samples (Figure 1). For the mesobenthos sample one core $\left(79 \mathrm{~cm}^{2}\right)$ was sectioned at the $10 \mathrm{~cm}$ horizon and this was sieved through 180 and $250 \mu \mathrm{m}$ meshes (excluding the $250 \mu \mathrm{m}$ fraction). For the meiobenthos samples three $20 \mathrm{ml}$ syringes were used to subsample a single core with a $0-5 \mathrm{~cm}$ section retained from each to produce a pooled sample of $10 \mathrm{~cm}^{2}$, which was then sieved through a $45 \mu \mathrm{m}$ mesh. In total $45-50$ individual cores $\left(\sim 0.35 \mathrm{~m}^{2}\right)$ were processed at each location. All the material was fixed in $4 \%$, borax buffered, formaldehyde.

\section{Sample treatment}

In the laboratory macro- and meso-benthos samples were enumerated and sorted to major taxa under a stereomicroscope and preserved in ethanol. All metazoan taxa 
retained on the sieves were considered. The organisms from the meiofauna samples were extracted by centrifugation in Ludox ${ }^{\circledR}$ (Platt \& Warwick, 1983). The collected specimens were enumerated, sorted to major taxa and preserved in ethanol. All the nematodes found in the samples were mounted, in anhydrous glycerol, on glass microscope slides (Platt \& Warwick, 1983).

Organism wet weights were estimated as the product of volume and specific gravity (Andrassy, 1956). A specific gravity of 1.13 was assumed for all the organisms used in the biomass estimation (Gerlach et al., 1985). Organism volumes were estimated by resolving the specimen bodies into a number of geometric figures ranging from cylinders and spheres to truncated cones. For Echinodea, $50 \%$ of the total volume was assumed to be soft tissue. For other hard bodied taxa (Bivalvia: Ostracoda), the volume of soft tissue could be determined directly.

The specimens were examined using a stereomicroscope (compound microscope in the case of mounted nematodes) fitted with a drawing tube that permitted a virtual image of the individual either being drawn or directly measured over the digitizing tablet of the image analyser (Sigma Scan Image Analysis, v. 2.0). The measurements were made at the highest magnification that provided sufficient field width to encompass the entire specimen to be measured. In cases where more than 150 specimens of the same taxon were present in a single sample, 100 individuals were chosen randomly for the biomass estimation and a density sub-sampling factor applied to that taxon accordingly. The sub-sampling was achieved by thoroughly dispersing all the organisms on a gridded Petri dish and measuring all the individuals within randomly selected squares, until at least 100 specimens had been measured. In total 8525 specimens were measured from the Fladen Ground site and 3164 specimens from the FSC site.

\section{Statistical treatment}

The simplest way to compare body sizes between the two sites is to use 'average individual biomass' (AIB), sample biomass divided by sample abundance (e.g. Bett \& Gage, 2000). As the samples were sieved through a nest of mesh sizes, the data can be analysed in three different ways: (1) the overall sample total combining all the sieve fractions $(500,355,250,180,45 \mu \mathrm{m})$ together (i.e. $>45 \mu \mathrm{m})$; (2) separate fractions including only the specimens retained on that particular sieve mesh (i.e. largest fraction $>500 \mu \mathrm{m}$, next fraction $<500 \mu \mathrm{m}$ but $>355 \mu \mathrm{m}$ etc.); and (3) cumulative fractions giving the notional catch as if each sieve had been used on its own (e.g. $>500,>355$, $>250,>180$, and $>45 \mu \mathrm{m})$. Total sample AIB values were calculated for all three data 'treatments' as a mean value of the five replicates from each site.

Carrying out regression analyses on conventional abundance size spectra (where the number of individuals is plotted in logarithmic size-classes; $\log _{10}-\log _{10}$ plots) can potentially reveal differences in the underlying size-structure. This approach is based on the idea that abundance decreases with increasing body size and that a community consisting of smaller organisms on average will display a significantly more negative slope in the regression. Although such analyses were performed for the two study locations (observed slopes -0.68 and -0.65 for Fladen Ground and FSC, respectively), it should be noted that this approach is still effectively reducing the underlying size-structure to a single figure that is therefore subjected to some of the same shortcomings as the AIB indices. Furthermore, regression analysis makes a number of assumptions (Sokal \& Rohlf, 1995) that are frequently not met in field data. Consequently a non-parametric technique was adopted.

The relative differences between the replicate body size accumulation curves and the different sites were assessed using the analysis of similarities (ANOSIM) routine provided by the PRIMER software (Clarke \& Green, 1988; Warwick \& Clarke, 1991). As applied here, the ANOSIM tests were based on analyses of dissimilarity matrices generated by summing the differences between the cumulative percentages of any two samples. This analysis was applied to the data set as a whole and to three major taxonomic (Polychaeta: Crustacea and Nematoda) groups separately.

\section{RESULTS}

The benthic communities at both sites were found to be typical of their respective areas (McIntyre, 1961; De Wilde et al., 1986; Eleftheriou \& Bashford, 1989; Bett, 2001). The mean absolute abundance and biomass values recorded in Fladen Ground were considerably higher than those observed at the deeper FSC site (Table 1). At both sites, polychaetes dominated the macrofauna and nematodes the meiofauna in terms of numbers and biomass. At the Fladen Ground site high numbers of bivalves (Veneridae), gastropods (Philinidae), and polychaetes (Opheliidae) were recorded in the smaller sieve fractions $(180-355 \mu \mathrm{m})$. Although some smaller macrofauna were found at the FSC site, their relative numbers were low in comparison to the Fladen Ground location.

Table 1. Summary statistics of benthic community abundance, biomass and average body size at shallow (Fladen Ground, $150 \mathrm{~m}$ ) and deepwater (FSC, Faroe-Shetland Channel, $1600 \mathrm{~m}$ ) sites based on five replicate sets at each location.

\begin{tabular}{|c|c|c|c|c|}
\hline Parameter & Units & Fladen Ground & FSC & $P$ \\
\hline Macrofauna abundance $>500 \mu \mathrm{m}$ & Ind $\mathrm{m}^{-2}$ & 8,403 & 2,988 & 0.01 \\
\hline Total abundance & Ind $\mathrm{m}^{-2}$ & 801,426 & 471,422 & n.s. \\
\hline Total biomass & $g(w w t) m^{-2}$ & 15.0 & 11.0 & n.s. \\
\hline AIB total & $\mathrm{g}(\mathrm{wwt})$ & $1.9 \times 10^{-5}$ & $2.7 \times 10^{-5}$ & n.s. \\
\hline $\mathrm{AIB}<500 \mu \mathrm{m}$ & $g(w w t)$ & $6.6 \times 10^{-6}$ & $2.8 \times 10^{-6}$ & 0.02 \\
\hline
\end{tabular}

AIB, average individual biomass; $P$, probability result of Mann-Whitney $U$-test comparison between the sites; n.s., not significant. 


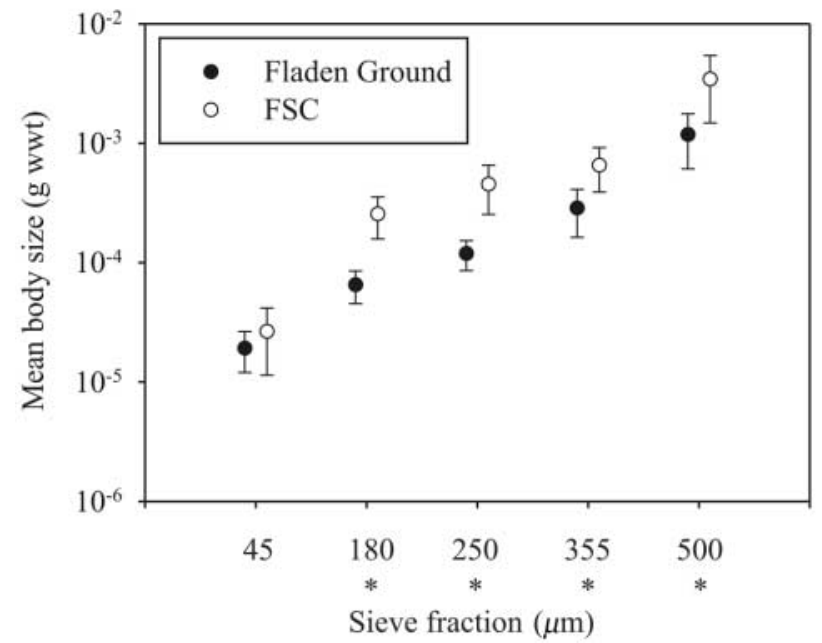

Figure 2. Mean body size for the accumulative sieve fractions. *Denotes a significant difference between the two sites (MannWhitney $U P<0.05$; error bars are 95\% confidence intervals).

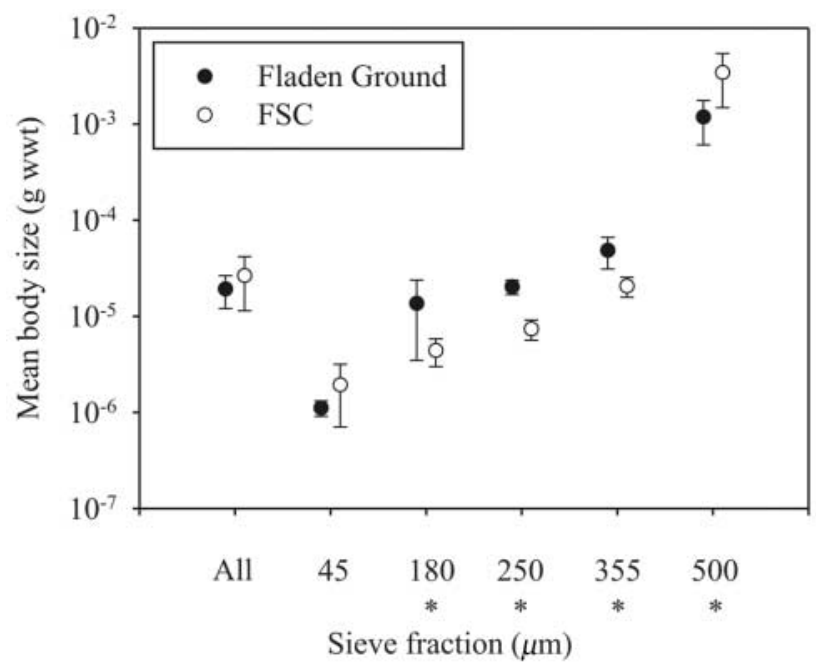

Figure 3. Mean body size for the individual sieve fractions. *Denotes a significant difference between the two sites (MannWhitney $U P<0.05$; error bars are $95 \%$ confidence intervals).

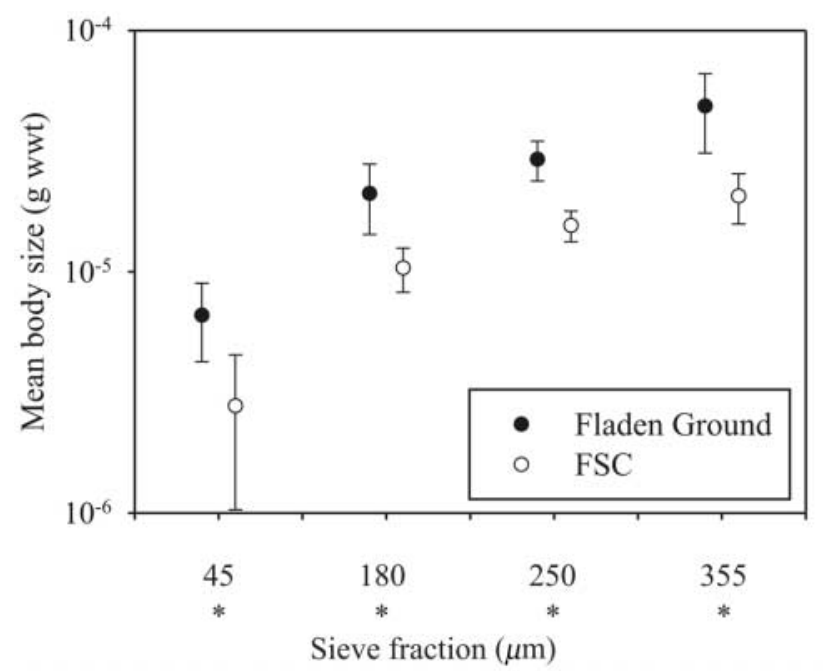

Figure 4. Mean body size for the accumulative sieve fractions (excluding the $500 \mu \mathrm{m})$. *Denotes a significant difference between the two sites (Mann-Whitney $U P<0.05$; error bars are $95 \%$ confidence intervals).
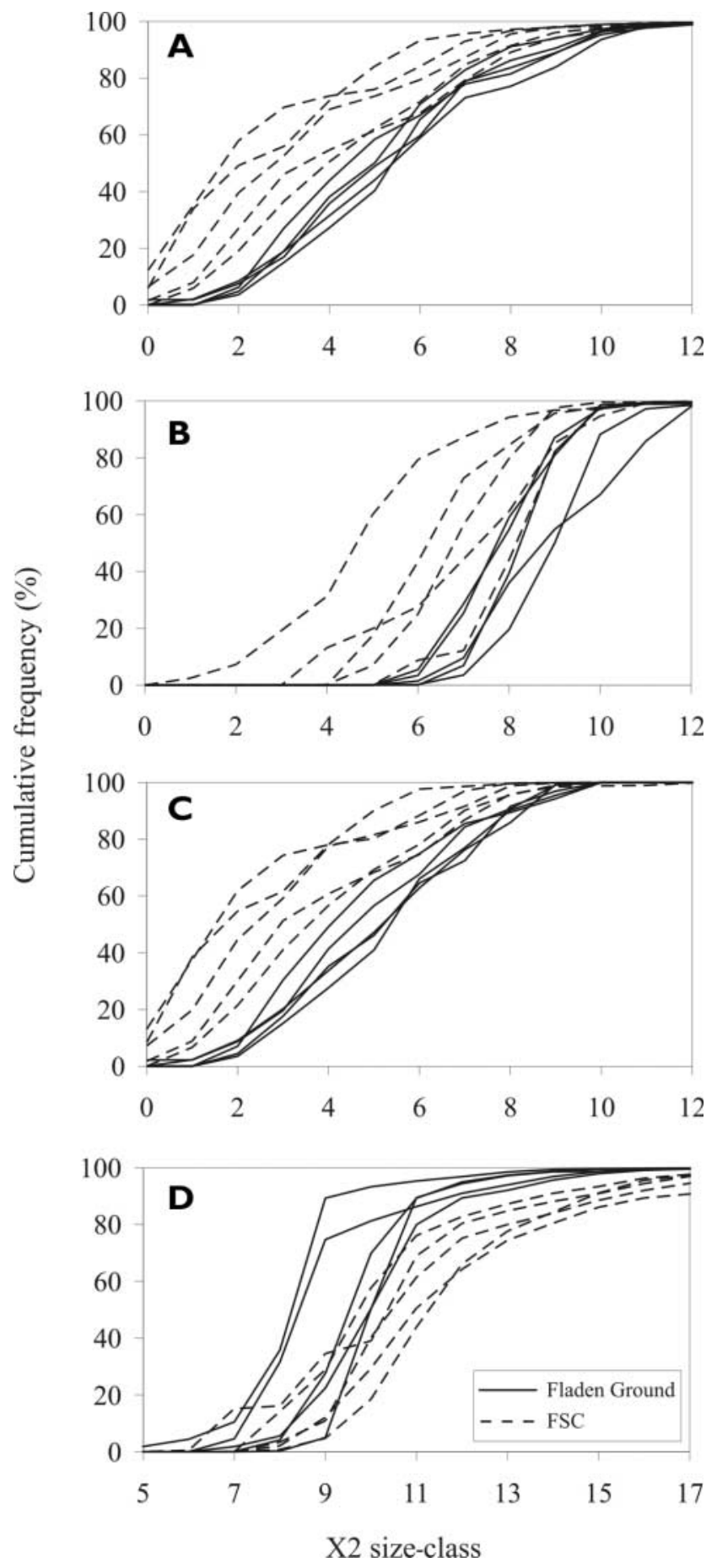

Figure 5. Body size accumulation curves for the (A) overall data set; (B) Crustacea; (C) Nematoda; and (D) Polychaeta. Only the relevant size-class ranges are shown for each graph.

The overall body size of metazoans (measured as AIB for all the sieve fractions combined) did not differ significantly between the two sites (Table 1; Figure 2: $45 \mu \mathrm{m}$ fraction includes all the measured organisms). Inspection of the accumulated fractions (Figure 2) reveals that average individual biomass at the FSC site was higher in all of the sieve fractions. However, the separate sieve fractions displayed an opposing trend with body size in Fladen Ground being larger in most of the fractions with the exception of $500 \mu \mathrm{m}$ (Figure 3). These observations imply that it is the presence of the largest individuals $(>500 \mu \mathrm{m})$ 
at the FSC site that contribute considerably to the observed AIB values. If the organisms retained on the $500 \mu \mathrm{m}$ sieve are excluded from the analysis, average individual biomass is found to be significantly larger in all the sieve fractions from the Fladen Ground site (Figure 4).

Figure 5A shows the overall body size accumulation curves for each replicate from the two study sites. The FSC curves all lie above the Fladen Ground ones over most of their range. This depicts an obvious shift in the distribution of body sizes between the two sites, with the FSG community being clearly dominated by smaller organisms. The body size distributions (i.e. the shape and position of the curves) were statistically tested by using ANOSIM and were found to be significantly different between the two sites $(P<0.01)$. The analysis of major taxa showed that both nematodes and crustaceans followed the same trend and that again there were significant differences between the two sites (Figure 5B \& C; $P<0.01)$. Polychaetes displayed an opposing trend (Figure 5D) with a higher proportion of smaller individuals encountered at the Fladen Ground site $(P<0.01)$.

\section{DISGUSSION}

Most of the studies that have previously attempted to investigate body size miniaturization in the deep sea have used average individual size to try to gauge changes in the underlying body size structure. The fact that these studies have provided contradictory results is not surprising considering the complexity and the limited value of AIB data. By definition average values consider all the individuals in the sample and thus can be highly sensitive to the presence of extreme data points. These can potentially mask the true trends in underlying size-structure, as rare large individuals have little influence on body size accumulation curves but can have a marked effect on AIB values. For example, in the present study the inclusion of larger individuals from the $500 \mu \mathrm{m}$ fraction at the deeper site was enough to skew the average values to the point that the body sizes appeared larger on all other sieve fractions. The body size accumulation curves clearly depict a significant shift towards smaller body sizes at the deeper site and only by excluding the largest organisms from the analysis were the AIB values able to reflect this trend. This highlights the limited value of attempting to reduce benthic body size distributions to a single average value.

The comparison of the body size accumulation curves for major taxa produced contradictory results. Nematodes and crustaceans followed the trend of the data set as a whole, whereas polychaetes displayed smaller body sizes at the Fladen Ground site. The deviation of polychaete body size structure from the general trend may have resulted from either different taxonomic composition and the associated recruitment histories or the degree to which the two sampling sites are subjected to habitat disturbance. For example, in the current study a high number of small polychaetes (Opheliidae) and molluscs (Veneridae: Philinidae) were encountered at the Fladen Ground site, suggesting that a relatively recent settlement event had taken place. The occurrence of large spat falls relatively late in the season is not unusual as, for example, Philinidae gastropods have been recorded to spawn throughout the summer with the larval settlement time typically more than 30 days (Hansen \& Ockelmann, 1991; Wilson, 2000). There was no evidence of recently settled juvenile macrofauna at the deeper FSC site.

The sampling location at Fladen Ground is also subjected to disturbance by extensive oil industry activity and fisheries whilst the FSG location represents an essentially undisturbed deep-sea environment. Environmental disturbance (e.g. pollution) has been shown to result in smaller body sizes of macrobenthic organisms, whereas meiobenthos may not display an obvious size difference between conservative and opportunistic species (Warwick, 1986). It is possible that the trends observed in the size accumulation curves of the major taxa reflected the increased disturbance levels at the Fladen Ground sampling site. This suggests that the macrobenthic organisms at the Fladen Ground site may have displayed a reduced body size in comparison to an undisturbed site with otherwise similar environmental conditions. Consequently, the observed shift in the body size distributions may be even more pronounced in undisturbed habitats.

Rex \& Etter (1998) stated that size-related adaptations to the environmental conditions in deep-sea benthos should be examined at species level with the measurements standardized to similar species assemblages and common growth stages. Although a species-level approach can help to elucidate some of the factors responsible for the sizedepth patterns, it is difficult to extend this approach to community level as it is not realistic to expect benthic communities to have a consistent taxonomic composition over a broad bathymetric range. Thiel's original hypothesis (1975) about body size miniaturization in deep-sea environments applied to benthic assemblages as a whole and hence a different approach may help to determine some of the causative factors at this level. One alternative is to use the non-taxonomic approach adopted in this study that assumes organisms of similar size to respond similarly to environmental constraints.

Thiel (1975) argued that the causative agent is the limited food supply, which results in smaller body sizes on average. He explained this by comparing the advantages of being either small or large in a food-limited environment. Although the cost of maintaining a given biomass of smaller organisms is higher than that required to maintain the same biomass of larger organisms, the high individual food demands of larger animals and the requirement to maintain a critical population density for reproduction generally favours smaller body sizes. This hypothesis generally applies to infauna (e.g. meio- and macro-fauna) that feed on the sediment locally. Organisms (e.g. some megafauna) with a broader home range can display increased body sizes with water depth as they benefit from reduced vulnerability to local extinction and are able to feed over larger areas hence utilizing their metabolic advantage (Thiel, 1979; Rex \& Etter, 1998).

With the exception of hydrothermal vents and cold seeps, the main food source for benthic communities is generally the organic matter synthesized in the overlying surface waters (Sokolova, 2000). The amount of organic matter reaching the sea-floor is often a function of water depth with the organic content decreasing with increasing bathymetric depth (Rowe, 1971). The flux of organic material to the sea-floor is not easy to determine and data for 
the two study sites are scarce. As most of the organic material that reaches the sea-floor is utilized by the fauna (Cole et al., 1987; Gage \& Tyler, 1991), the standing stock of benthos is a good indirect measurement of this flux. Although primary production at the two study sites has been reported to be similar $\left(\sim 1 \mathrm{~g} \mathrm{C} \mathrm{m}^{-2} \mathrm{~d}^{-1}\right.$; Cadée, 1986; Riegman \& Kraay, 2001), there are differences in the benthic biomass levels (Table 1). Using Suess' (1980) equation linking primary production of organic carbon in surface waters to particulate organic carbon flux to depth we can estimate that the FSC site receives about $10 \%$ of the organic input that reaches the Fladen Ground site. Although the Suess' equation has been criticized (Lutz et al., 2002) and there may be additional organic inputs to the North Sea (Austen et al., 1991), it may nevertheless be reasonable to suggest that there is an order of magnitude difference in the organic matter flux to the two study sites. It is therefore conceivable that food limitation may act as a contributing factor in controlling the optimal body size of benthic communities resulting in the smaller body size distribution observed at the FSC site in the current study.

A number of other environmental factors have been suggested to explain differences in body size structure between contrasting habitats and perhaps the most obvious one in the analysis of benthic communities is that of sediment grain size distribution. For instance, Schwinghamer (1981) hypothesized that sediment granulometry determined the size-distributions of infaunal organisms and that shifts would occur in the size-spectra in response to changes in particle size composition but subsequent studies have frequently provided contrary evidence (Warwick, 1984; Duplisea \& Drgas, 1999; Leaper et al., 2001). Similarly, Chapelle \& Peck (1999) suggested that individual body size may be correlated with dissolved oxygen concentration but in this study both the bottom water oxygen levels and the particle sizedistribution of sediments were very similar suggesting that the differences in size-distributions did not result from variations in these parameter values. Other factors such as temperature, hydrodynamics and predation may also influence the observed size-structures.

The results from this study are based on data from only two sampling stations located on the UK continental shelf and slope and so their wider implications must be interpreted with caution. The investigation of cumulative body size distribution patterns for a number of stations across a bathymetric gradient are required to further assess the existing hypothesis concerning the size-depth pattern. The results from the two locations do, however, provide robust evidence for body size reduction in the deep sea, with food availability acting as a possible control.

\section{REFERENCES}

Andrassy, I., 1956. Determination of volume and weight of nematodes. In English translations of selected East European papers in nematology (ed. B.M. Zuckerman et al.), pp. 73-84. University of Massachusetts Press.

Austen, M.C., Buchanan, J.B., Hunt, H.G., Josefson, A.B. \& Kendall, M.A., 1991. Comparison of long-term trends in benthic and pelagic communities of the North Sea. Fournal of the Marine Biological Association of the United Kingdom, 71, 179-190.
Bett, B.J., 2001. UK Atlantic margin environmental survey: introduction and overview of bathyal benthic biology. Continental Shelf Research, 21, 917-956.

Bett, B.J. \& Gage, J.D., 2000. Section 6.2. Practical approaches to monitoring the deep-sea environment of the UK Atlantic Margin. In Environmental Surveys of the Seafloor of the UK Atlantic Margin, Atlantic Frontier Environmental Network [CD-ROM]. Available from Geotek Limited, Daventry, Northants, NN11 5EA, UK. ISBN 09538399-0-7.

Cadée, G.C., 1986. Organic carbon in the water column and its sedimentation, Fladen Ground (North Sea), May 1983. Netherlands Journal of Sea Research, 20, 347-358.

Carey, A.G. Jr, 1981. A comparison of benthic infaunal abundance on two abyssal plains in the northeast Pacific Ocean. Deep-Sea Research, 28, 467-479.

Chapelle, G. \& Peck, L.S., 1999. Polar gigantism dictated by oxygen availability. Nature, London, 399, 144-145.

Clarke, A.H., 1960. A giant ultraabyssal Cocculina (C. superba, n.sp.) from the Argentina Basin. Natural History Papers, National Museum of Canada, 7, 1-4.

Clarke, K.R., 1990. Comparisons of dominance curves. Fournal of Experimental Marine Biology and Ecology, 138, 143-157.

Clarke, K.R. \& Green, R.H., 1988. Statistical design and analysis for a 'biological effects' study. Marine Ecology Progress Series, 46, 213-226.

Cole, J.J., Honjo, S. \& Erez, J., 1987. Benthic decomposition of organic matter at a deep-water site in the Panama Basin. Nature, London, 327, 703-704.

De Wilde, P.A.W.J., Berghuis, E.M. \& Kok, A., 1986. Biomass and activity of benthic fauna on the Fladen Ground (Northern North Sea). Netherlands Fournal of Sea Research, 20, 313-323.

Duplisea, D.E. \& Drgas, A., 1999. Sensitivity of a benthic, metazoan, biomass size spectrum to differences in sediment granulometry. Marine Ecology Progress Series, 177, 73-81.

Eleftheriou, A. \& Basford, D.J., 1989. The macrobenthic infauna of the offshore Northern North Sea. Fournal of the Marine Biological Association of the United Kingdom, 69, 123-143.

Gage, J.D., 1977. Structure of the abyssal macrobenthic community in the Rockall Trough. In Biology of benthic organisms (ed. B.F. Keegan et al.), pp. 247-260. Oxford: Pergamon Press.

Gage, J.D. \& Tyler, P.A., 1991. Deep sea biology: a natural history of organisms at the deep sea floor. Cambridge: Cambridge University Press.

Gage, J.D. \& Bett, B.J., 2005. Deep-sea benthic sampling. In Methods for the study of marine benthos (ed. A. Eleftheriou and A. McIntyre), pp. 273-325. Oxford: Blackwell Publishing.

Gerlach, S.A., Hahn, A.E. \& Schrage, M., 1985. Size spectra of benthic biomass and metabolism. Marine Ecology Progress Series, 26, 161-173.

Hansen, B. \& Ockelmann, K.W., 1991. Feeding behaviour in larvae of the opisthobranch Philine aperta. I. Growth and functional response at the different developmental stages. Marine Biology, 111, 255-261.

Jennings, S. et al., 1999. Fishing effects in northeast Atlantic shelf seas: patterns in fishing effort, diversity and community structure. III. International trawling effort in the North Sea: an analysis of spatial and temporal trends. Fisheries Research, 40, 125-134.

Lambshead, P.J.D., Platt, H.M. \& Shaw, K.M., 1983. The detection of differences among assemblages of marine benthic species based on an assessment of dominance and diversity. Fournal of Natural History, 17, 859-874.

Leaper, R., Raffaelli, D., Emes, C. \& Manly, B., 2001. Constraints on body-size distributions: an experimental test of the habitat architecture hypothesis. Fournal of Animal Ecology, 70, 248-259. 
Lee, A.J., 1980. North Sea: physical oceanography. In The northwest European shelf seas: the sea bed and the sea in motion II. Physical and chemical oceanography, and physical resources (ed. F.T. Banner et al.), pp. 467-493. Amsterdam: Elsevier.

Lutz, M., Dunbar, R.L. \& Caldeira, K., 2002. Regional variability in the vertical flux of particulate organic carbon in the ocean interior. Global Biogeochemical Cycles, 16, 91-110.

Magurran, A.E., 2004. Measuring biological diversity. Oxford: Blackwell Publishing.

McIntyre, A.D., 1961. Quantative differences in the fauna of boreal mud associations. Fournal of the Marine Biological Association of the United Kingdom, 41, 599-616.

Platt, H.M. \& Warwick, R.M., 1983. Free-living marine nematodes. Part I, British Enoplids. Synopsis of the British fauna. Cambridge: Cambridge University Press.

Polloni, P., Haedrich, R., Rowe, G. \& Clifford, C.H., 1979. The size-depth relationship in deep ocean animals. Internationale Revue der Gesamten Hydrobiologie, 64, 39-46.

Rex, M.A. \& Etter, R.J., 1998. Bathymetric patterns of body size: implications for deep-sea biodiversity. Deep-Sea Research II, 45, 103-127.

Riegman, R. \& Kraay, G.W., 2001. Phytoplankton community structure derived from HPLC analysis of pigments in the FSC during summer 1999 the distribution of taxonomic groups in relation to physical/chemical condition in the photic zone. Fournal of Plankton Research, 23, 191-205.

Rowe, G.T., 1971. Benthic biomass and surface productivity. In Fertility of the sea, vol. 2 (ed. J.D. Costlow), pp. 441-454. New York: Gordon \& Breach.

Rowe, G.T. \& Staresinic, N., 1979. Sources of organic matter to the deep-sea benthos. Ambio Special Report, 6, 19-23.

Schwinghamer, P., 1981. Characteristic size distributions of integral benthic communities. Canadian Fournal of Fisheries and Aquatic Sciences, 38, 1255-1263.

Shirayama, Y., 1983. Size structure of deep-sea meio- and macrobenthos in the western Pacific. Internationale Revue der Gesamten Hydrobiologie, 68, 799-810.

Smith, K.L. Jr \& Hinga, K.R., 1983. Sediment community respiration in the deep sea. In Deep-sea biology (ed. G.T. Rowe), pp. 331-370. New York: John Wiley \& Sons.

Soetaert, K. \& Heip, C., 1989. The size structure of nematode assemblages along a Mediterranean deep-sea transect. DeepSea Research Part A, 36, 93-102.
Sokal, R.R. \& Rohlf, F.J., 1995. Biometry: the principles and practice of statistics in biological research. New York: WH Freeman \& Company.

Sokolova, M.N., 2000. Feeding and trophic structure of the deep-sea macrobenthos. New Delhi: Amerind Publishing Company.

Soltwedel, T., Pfannkuche, O. \& Thiel, H., 1996. The size structure of deep-sea meiobenthos in the north-eastern Atlantic: nematode size spectra in relation to environmental variables. Fournal of the Marine Biological Association of the United Kingdom, 76, 327-344.

Suess, E., 1980. Particulate organic carbon flux in the oceans: surface productivity and oxygen utilization. Nature, London, 288, 260-263.

Thiel, H., 1975. The size structure of the deep-sea benthos. Internationale Revue der Gesamten Hydrobiologie, 60, 575-606.

Thiel, H., 1979. Structural aspects of the deep-sea benthos. Ambio Special Report, 6, 25-31.

Thurston, M.H., 1979. Scavenging abyssal amphipods from the north-east Atlantic Ocean. Marine Biology, 51, 55-68.

Tietjen, J.H., 1989. Ecology of deep-sea nematodes from the Puerto Rico Trench area and Hatteras Abyssal Plain. Deep-Sea Research, 36, 1579-1594.

Turrell, W.R., Slesser, G., Adams, R.D., Payne, R. \& Gillibrand, P.A., 1999. Decadal variability in the composition of FaroeShetland Channel bottom water. Deep-Sea Research I, 46, 1-25.

Warwick, R.M., 1984. Species size distributions in marine benthic communities. Oecologia, 61, 32-40.

Warwick, R.M., 1986. A new method for detecting pollution effects on marine macrobenthic communities. Marine Biology, 92, 557-562.

Warwick. R.M. \& Clarke, K.R., 1991. A comparison of some methods for analysing changes in benthic community structure. Fournal of the Marine Biological Association of the United Kingdom, 71, 225-244.

Wilson, E., 2000. Philine aperta. Lobe shell. Marine life information network: biology and sensitivity key information sub-programme (on-line). Plymouth: Marine Biological Association of the United Kingdom. http:// www.marlin.ac.uk/species/philiniaperta.htms

Wolff, T., 1962. The systematics and biology of bathyal and abyssal Isopoda, Asellota. Galathea Report, 6, 1-358.

Submitted 5 January 2006. Accepted 15 October 2006. 